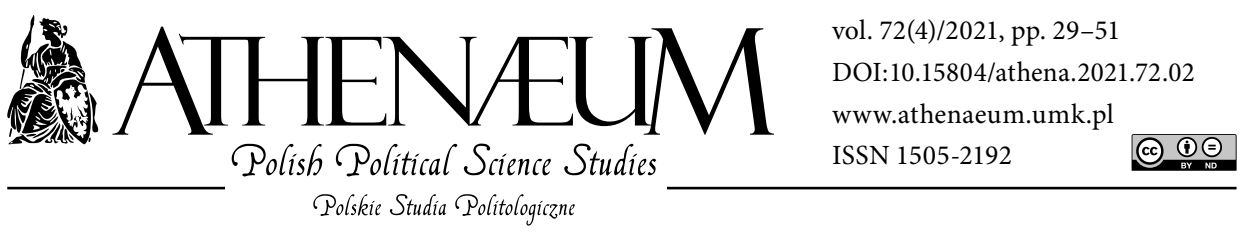

\title{
POLITICIZATION AS A FACTOR OF SHAPING NEWS IN THE PUBLIC SERVICE MEDIA: A CASE STUDY ON PUBLIC TELEVISION IN POLAND
}

\author{
POLITYZACJA JAKO CZYNNIK W KSZTAŁTOWANIU \\ PRZEKAZU MEDIALNEGO W TVP SA - STUDIUM PRZYPADKU \\ Agnieszka Węglińska* • , Łukasz Szurmiński** ๑), \\ Maria Wąsicka-Sroczyńska***
}

\begin{abstract}
This study addresses the positioning of Poland's public television network (TVP) within the country's contemporary political system. In a democratic country, the media laws determine journalism practices and the media content. In this study, three perspectives of analysis were used to assess the relationship between the process of politicization and the selection and shaping of news. Three areas of the TVP's politicization were focused on: media law, journalists, and media content, to show the dependence between these fields and how the news was shaped and presented. Mixed methods of empirical research were used to investigate the raised issues; the authors focused on Polish parliament papers $(\mathrm{N}=$ 45) regarding the legal regulations of Polish public broadcasters during the period of 2015-2016; conducted in-depth interviews with journalists with TVP experience $(\mathrm{N}=20)$; and performed
\end{abstract}

Niniejsze opracowanie dotyczy pozycji polskiej telewizji publicznej (TVP) w systemie politycznym kraju. W demokratycznym państwie prawa dotyczące mediów określają praktyki dziennikarskie i ich zawartość. W niniejszym badaniu wykorzystano trzy perspektywy badawcze do oceny związku między procesem upolitycznienia a selekcją i kształtowaniem wiadomości. Skoncentrowano się na trzech obszarach upolitycznienia TVP - prawie medialnym, dziennikarzach i treściach medialnych - aby pokazać zależności między nimi oraz sposób kształtowania i prezentowania wiadomości. Zastosowano mieszane metody badań empirycznych do zbadania poruszonych przez autorów zagadnień. W celu weryfikacji problemu badawczego przeprowadzono analizy sprawozdań $\mathrm{z}$ obrad polskiego parlamentu $(\mathrm{N}=45)$ dotyczących regulacji prawnych polskich nadawców publicz-

* University of Lower Silesia, Faculty of Applied Studies and Administration.

$* \star$ University of Warsaw, Faculty of Journalism, Information and Book Studies.

$* * *$ Adam Mickiewicz University in Poznań, Faculty of Political Science and Journalism. 
a content analysis of the Polish public television channel TVP1's "Newsnight" news program during the period of February 4-10, 2019. We found that an increased level of politicization at Poland's TVP led to direct influence on the shape and selection of news.

Keywords: politicization; Newsnight; Polish public broadcasters; journalism; self-censorship; news shaping; media content nych w latach 2015-2016; wywiady pogłębione z dziennikarzami w TVP $(\mathrm{N}=20)$; i analizę treści programu informacyjnego „Wiadomości” TVP1 w okresie 4-10 lutego 2019 r. Autorzy stwierdzili, że czynnik jakim jest upolitycznienie TVP oddziałał na praktykę dziennikarską i zawartość przekazu informacyjnego stacji

Słowa kluczowe: polityzacja; Wiadomości; TVP; dziennikarstwo; autocenzura; kształtowanie przekazu medialnego; zawartość mediów

\section{INTRODUCTION}

A country's political system, history, and traditions play an important part in shaping its public media (Chadwick, 2013). The 1993 Broadcasting Act and the 1997 Constitution of the Polish Republic have influenced the legislation of Polish public media, and the former designated a dual-media system, thus implementing the transformation of Poland's media (Chruściak, 2007). The creators of the Polish media system drew inspiration from the French model of that time, which saw public media granted the legal status of a commercial company (Ociepka, 2003; Węglińska, 2018). The Krajowa Rada Radiofonii i Telewizji [KRRiT; National Broadcasting Council], controls the media (the regulators), and may be found in the Broadcasting Act and in the Polish Constitution (Węglińska, 2018). The legislation's goal was to make KRRiT an independent regulatory body. The Constitution does not specify the public authorities that this body should be in contact with or reveal how many members it should comprise of (Grochowski, 2015). In Polish media law, public service media play the crucial role as a part of dual media system and one of guarantors of democracy.

Poland's public television network, Telewizja Polska S.A. [TVP; Polish Television Ltd.,], has several long-term unsolved problems. The first is from unregulated license fee payments, as only 7.6\% of Poles pay this fee (Jakubowicz, 2007, Węglińska, 2018). The second is from a very high level of politicization (Wąsicka, 2014; Węglińska, 2018; Dobek-Ostrowska, 2011, 2015, 2019), and from the TVP's authorities being related to the ruling party.

When the Law and Justice political party (PiS) regained power in Poland in 2015 with a very populist, conservative program, it initiated profound reforms. Its charismatic leader, Jarosław Kaczyński, appeared to view public media as a crucial 
tool for maintaining power. The TVP has recently been strongly influenced by PiS politicians; partly as a result of the latest amendments to the Broadcasting Act $(2015,2016)$. The freedom and impartiality of public service media in Poland has been constantly violated by the ruling party's representatives. Similar processes have also been observed in other post-communist countries (Dobek-Ostrowska, 2019). It is important to study journalism in Central Eastern Europe (CEE) and to diagnose processes occurring in less frequently analyzed media systems. The main aim of this study is to present the influences behind the politicization of the news shaping at the TVP in regard to the levels of law, journalism practices, and news content.

To summarize the introduction, first, we assess the concept of politicization in the media in Poland. Second, we describe the three analyses used in this study. We assess the legal regulations of Polish public broadcasters through a documentation assessment. Third, we review the impact of politicization experienced by journalists working at the TVP using interviews. Finally, we provide the case study of TVP1's "Newsnight" program to reveal the relationship between the media law, journalism, and news content in Poland.

\section{THE CONCEPT OF POLITICIZATION IN THE MEDIA}

Dobek-Ostrowska (2015) classified four main media systems among CEE countries. Poland and the West Slavonic and Baltic states were classified as an example of a hybrid liberal model. Bulgaria, Croatia, Hungary, Romania, and Serbia were defined as a politicized media model. Moldova, Macedonia, Montenegro, Albania, Bosnia and Herzegovina were examples of a transitional media model, and the authoritarian model included Belarus and Russia. This classification provides a basis for a comparative research of the CEE media systems with the systems used in other countries. Brüggemann et al. (2014, $2016,2017)$ prepared their own classification of the CEE media systems based on Hallin and Mancini's $(2004,2012)$ system. This new typology included new variables such as ownership regulation, direct and indirect subsidies, freedom of the press, online news use, centralization of the media, and foreign ownership. Both typologies clearly indicate the relationship between political systems, media law, and public service media. We note that the political affiliation at the TVP and the increase of politicization within public service media have been recently visible. 
The concept of the politicization of the media is inextricably linked to the mediatization of politics, in Poland as well, just like mass media is related to the sphere of politics in a complex way, and can be described in regard to the interests, aims, and mutual relations of these two systems. Oniszczuk (2011) determined three paradigms of mutual dependencies. The first is the paradigm of shared power, which practically places the media in the role of the fourth power. The paradigm of instrumentalization focuses on the attempt of one system to dominate over another. Mediatization would be perceived as the supremacy of the media system (Strömbäck, 2008; Dobek-Ostrowska, 2018), while politicization assumes the media as an instrument of a political system. We can diagnose that since 2015, TVP has reflected this particular model (Węglińska, 2018; Wąsicka-Sroczyńska, 2019). The third paradigm is defined by the system's independence and symbiosis. In regard to the second paradigm, the politicization of the media is defined as an attempt at political domination over the media system and its usage in realizing its own political goals. As Adamowski writes, this is "an explicit encroachment and presence of politics (in all its manifestations and forms) in the everyday functioning of mass media" (Adamowski, 2007, p. 67). The following activities or instruments can be perceived as manifestations of the politicization of the media (Oniszczuk, 2011, pp. 20-21):

- The development of symbolic politics that focuses public opinion on selected symbolic, emotional, or current topics, and postpones gaps in political programs or failures in their implementation;

- Personal politics that leads the appointing party's supporters to the most important positions in the media, and is specific to post-communist countries;

- Focusing media interest on the topics that are important from a party's viewpoint and useful for its political goals;

- Exerting direct or indirect political pressure on the media (in the form of changes in legal regulations) which would serve their political subordination. These legal instruments will be described in detail below.

\section{RESEARCH BACKGROUND}

The politicization of the media seems to be a problem that has been perceived and analyzed throughout different global regions such as South Korea (Haggard \& You, 2015), India, Romania (Tocia, 2018), and Poland (Dopierała \& Ossowski, 
2018; Surowiec, Kania-Lundholm \& Winiarska-Brodowska, 2020; Węglińska, 2018; Wąsicka, 2014; Wąsicka-Sroczyńska, 2019), despite these countries' having seemingly well-grounded democracies. Smyth and Oates (2015) mentioned the politicization of the media as a problem for public opinion in Russia to interpret state narratives within public media.

The politicization of the media is studied in regard to the different programs or political context (Haggard \& You, 2015), also in the context of discourse on both politicization and de-politicization of media agencies in Great Britain (Schroeter, 2018). There are also studies of news programs in Poland (Dopierała \& Ossowski, 2018) and projects discussing journalists' freedom of speech (Tocia, 2018), and the politicization of infotainment in Italy (Splendore \& Domaneschi, 2017). The phenomenon is considered as a risk factor in regard to the media's pluralism versus its ownership or control (Valcke et al., 2010).

Poland has faced increasing challenges in regard to freedom of speech and media independence since 2015. The worsening situation has been observed by Reporters Without Borders (2019) who discuss the growing occurrence of hate speech within the Polish media. Several studies concerning the mutual relations (influences, dependencies) of politics and the media during the last decade in Poland have been discussed. Hess (2010) suggested that the success and power of politicians depended on their media and party base relations. Wąsicka (2014; Wąsicka-Sroczyńska, 2019) raised concerns over the questionable objectivity of the media supervisory body, the KRRiT, whose members are appointed by politicians. In turn, the Council appoints public media authorities and therefore they "remain in a continuous sphere of political influence... [and the] strong desire to subordinate the public broadcaster stems from the belief that 'the one who has television, has the power', which made public media a 'political payoff' or 'prize' meant for the political party which wins the elections" (Wąsicka, 2014, p. 152). Surowiec, Kania-Lundholm, and Winiarska-Brodowska (2020) discussed the new politics of illiberal media regulations.

The process of the politicization has been observed and analyzed. A comparative study was conducted (Dopierała \& Ossowski, 2018) concerning news programs on public (TVP1) and private (TVN, part of the Discovery channel) channels in selected periods of 2014 and 2017, that is, before the seizure of power by PiS during a mid-term of their government. It proved that the main news program for the public TV channel had undergone a huge, negative transformation in that time. The problem of politicization was widely discussed and researched, yet there remains a lack of comprehensive description concerning the 
relationships between political factors and news shaping. This study is devoted to this problem of politicization. However, the predominant perspective is on news creation and selection.

\section{EMPIRICAL RESEARCH METHODOLOGY}

We analyzed the relationships between news creation and the process of politicization in public television in Poland. We used mixed methods (Creswell, 2013) to answer these questions, and more detail is provided in each of the three parts of the following media law (the Broadcasting Act and its amendments), experience of journalists, and media content analysis. Both the qualitative and quantitative study are complete each on their own (Morgan, 2013). The combining of qualitative and quantitative methods and research tools was intentional. We investigated the legislators' actions (analysis of parliamentary documents). Then we used in-depth interviews to present practical operation of legal acts in journalists of TVP professional work. Finally we presented the last link of the chain - media content (qualitative and quantitative content analysis). The research procedure designed that way allowed us to obtain more comprehensive results and conclusions. The research questions (RQs) were as follows:

- RQ1: What kind of factors related to the process of politicization of Polish public television are important in news shaping?

- RQ2: Is politicization the most important aspect influencing information selection and news construction by journalists at TVP?

- RQ3: Are institutional and legal norms able to ensure the independence of the public broadcaster?

- RQ4: How does the politicization of the media affect the exposure of politicians and the selection of experts and commentators for the TVP1 news program Wiadomości [Newsnight]?

\section{POLISH PUBLIC TELEVISION BROADCASTERS IN LIGHT OF LEGAL REGULATIONS}

Legislation establishes legal, institutional and political frameworks for particular spheres of life; it should be perceived as an instrument put at the disposal of political parties which exerts a real influence on the areas that are being reformed 
and entitles those parties to carry out specific actions. It is therefore necessary to analyze legislative acts. This part of the paper focuses on laws concerning TVP and the KRRiT.

Over the course of 26 years following the adoption of the first Broadcasting Act (1993-2019), parliamentary elections were held eight times and they brought victory for political parties representing different sides of the political scene. At that time particular political parties' interest in public media was steadily growing. As many as twenty-six draft amendments to the Broadcasting Act were put forward, which raised critical issues related to KRRiT and public broadcasters: the number of members of particular bodies, rotation in office, dismissals, and the scope of duties. Out of this large number of draft laws, only seven amendments were adopted $(1995,2004,2005,2006,2010,2015,2016)$. Additionally, the issue of license fees was regulated in a separate act (2005), and the position of the body supervising and regulating the Polish media market was established in the Constitution (1997). All of these legal regulations were criticized to a greater or lesser extent, but especially noteworthy are amendments made at the beginning of the previous parliamentary term, i.e., in 2015-2016, which radically changed the state of affairs.

The analysis conducted for the purposes of this paper covered documents illustrating legislative processes that resulted in the passing of two laws, in 2015 and 2016, which undoubtedly played the greatest role in changing the functioning of the KRRiT and public broadcasters. About $45(\mathrm{~N}=45)$ documents were analyzed: Sejm and Senate papers, reports of both chambers' sessions and proceedings of the meetings of the Sejm's and Senate's Culture and Media Committee.

Two months after the parliamentary elections, on December 28, 2015, Sejm deputies belonging to the winning right-wing party PiS submitted a short draft amendment of the Broadcasting Act, which included revolutionary premises (Paper No. 158 of December 28, 2015).

In this amendment $\mathrm{PiS}$ proposed several radical changes:

1. Depriving the KRRiT of the power to organize open and transparent contests for positions in the management and supervisory bodies of public broadcasters;

2. Abolishing the requirement to hold contests for membership in such bodies;

3. Giving the Minister of the Treasury the power to appoint and dismiss members of the management and supervisory bodies of public broadcasters; 
4. Modifying the requirements for membership in these bodies;

5. Eliminating the closed-ended list of situations warranting the dismissal of members of the management and supervisory boards of the public radio and the TVP;

6. Abolishing rotation in office for management and supervisory bodies;

7. No vacatio legis, which means that the law went into effect immediately;

8. Terminating the term in office of the existing members of management and supervisory bodies once the law entered into force, on condition of finding successors for the retiring members. This was nothing new, as solutions of this kind had been used before.

PiS members justified the proposals by saying that their predecessors' actions had driven the public media into a bad state (Report of the Sejm's $7^{\text {th }}$ session of December 30,2015, pp. 218, 219). Politicians belonging to the ruling party declared that they themselves were motivated by the desire to "restore the importance of public media by healing their organizational structures as well as their way of functioning through substantial financial reinforcement" and were aiming to "achieve the primary goal - bringing public media back to the Polish people" (Report of the Sejm's $7^{\text {th }}$ session of December 30, 2015, p. 168). The parliamentary opposition, represented by the centrist political party Platforma Obywatelska [PO; "Civic Platform"], which had been in power for the past eight years (two parliamentary terms), and by the liberal centrist party Nowoczesna [.N; "Modern"], strongly opposed the bills and stated that PiS "under the cover of night [...] [was] putting an end to public media and is, purely and simply, creating state-owned media... or, as a matter of fact, party-controlled media" (Report of the Sejm's $7^{\text {th }}$ session of December 30, 2015, p. 169). Moreover, they referred to the activities undertaken by PiS members as an attack on public media aimed at gaining personnel-based control over public broadcasters (see: Report of the Sejm's $7^{\text {th }}$ session of December 29,2015). Representatives of the populist party Kukiz'15 were far less critical.

Representatives of PO and Nowoczesna undertook activities aimed to moderate PiS' draft, but their proposals were effectively rejected by the ruling party, which could afford to do so because it was the first political party in the history after the Round Table to have won the majority in Parliament. PiS accepted only some minor amendments they themselves had submitted, and then passed an amendment to the Broadcasting Act in 2015 in that form (Act of December 30, 2015).

This amendment attracted interest from the European Union (EU), i.e., more specifically from the European Commission (EC), European Broadcasting Union 
(EBU), and Commissioner for Digital Economy and Society. Representatives of these institutions made negative comments about the provisions of this act, which they recognized as a threat to the independence and pluralism of public broadcasters (IAR, 2015, 2016a, 2016b). As a result, Poland became the first country in EU history for which the EC initiated a rule of law compliance assessment procedure. That, however, did not stop PiS or the President of Poland, Andrzej Duda, a former member of this party, who then signed the media law amendment despite the appeals from opposition and the EU. The next day, Jacek Kurski became TVP's Chairman. When assuming his office, Kurski, a journalist and, most of all, a PiS member of long standing, declared himself a guarantor of independent public media, but the personnel- and program-related changes introduced in 2016-2019 in public television did not support his claim. Examples confirming this conclusion can be found by analyzing interviews with TVP's journalists, as well as the content of the main edition of the news program Wiadomości [Newsnight] as described later in this paper.

Here, it should be noted that - as early as June 2016 - PiS succeeded in adopting another amendment (Paper No. 592 of June 7, 2016; Act of June 29, 2016), based on which Rada Mediów Narodowych [RMN; National Media Council] was established; it was a new body tasked with the gradual transformation of public radio and television broadcasters into national radio and television institutions (Paper No. 444 of April 20, 2016). The RMN took over responsibilities concerning public broadcasters, which had been taken from the KRRiT in December 2015 and passed on to the Minister of the Treasury, i.e., appointing and dismissing members of the management and supervisory bodies of public broadcasters.

Also, the RMN's rules of operation were specified. The RMN's composition was determined by the Sejm, which appointed three of its members, and by the President, who selected two of its members from candidates proposed by parliamentary opposition parties. It also became possible to dismiss members of the council before the end of the six-year term of office in strictly defined cases. All of this, according to the authors of these ideas, was to ensure the long-awaited independence of the RMN and public media (Report of the Sejm's $20^{\text {th }}$ Session of June 9, 2016; Report of the Sejm's $21^{\text {st }}$ Session of June 21, 2016).

This bill also received many negative comments, namely from the chairman of the KRRiT (Przewodniczacy KRRiT..., 2016) and from representatives of the parliamentary opposition, who - in contrast to the previous year's parliamentary work - were unanimous this time. G. Frugo (.N), among others, spoke on behalf of the opposition: "We were supposed to have [...] a new public media system, 
but what we see here is another step in the process of destroying Poland" (Report of the Sejm's 20 ${ }^{\text {th }}$ Session of June 9, 2016, p. 344). K. Paszczyk from Polskie Stronnictwo Ludowe [PSL; Polish People's Party] stated: “The new regulations concerning public media mean that they will be politicized, less independent, and managed in a centralized way" (Report of the Sejm's $21^{\text {st }}$ Session of June 21, 2016). Opposition politicians unanimously asserted that PiS had failed to deliver on their promise to prepare a comprehensive legislative act. Instead, PiS had again presented a personnel-focused bill that was aimed to continue and consolidate the state of affairs introduced six months ago and thereby further bring public broadcasters under one party's control. Concerns about these matters were even more justified when it was mostly former or existing members of PiS, having previous experience with journalism or having worked within the structures of the KRRiT and public broadcasters in the past, who became appointed as members of the RMN and the KRRiT.

This amendment was an attempt to partially meet a number of commitments undertaken during proceedings on the bill in 2015, as outlined below. First, it had been declared that regulations introduced by that amendment would cease to be effective on June 30,2016, which meant that a lack of legislative action would be synonymous with a return to the legal framework existing before December 2015. Secondly, it had been emphasized that the so-called "small law" from 2015 was of minor importance and "[conferred] powers" regarding the appointment of members of the management and supervisory bodies of public broadcasters "on the Minister of the Treasury for a certain limited period of time" (Record of a Joint Meeting..., 2015). Thirdly, it had been promised that the law was to be "the first phase of a Polish public media reform aimed to establish a national media system" (Bulletin, 2015, p. 25; Record of a Joint Meeting..., 2015) and was to be in force as "an interim act until a profound reform draft law [was] submitted dealing with the structure, form of functioning, and financing of national media, which [would] happen very soon" (Report of the Sejm's $7^{\text {th }}$ Session of December 29, 2015, p. 191; Bulletin, 2015, p. 25). It was the last of the above-mentioned promises, and the most important one, that was not fulfilled because no widely discussed, comprehensive amendment to the Broadcasting Act ever came forward.

In the summary of this part, it is worthwhile to mention a similar situation that arose in 2005, when PiS, having won both the presidential and the parliamentary elections, similarly to 2015, gained full legislative and executive power. At that time, PiS also succeeded in passing an amendment to the Broadcasting Act in a similar way, i.e., by legislating it at a very fast pace, without 
public consultation, and against the will of opposition parties. In those days, that amendment was the largest attempt at amending this law and one that had the most serious consequences (since 1995) (Wąsicka-Sroczyńska, 2019). It was directed towards gaining personnel-based control over the KRRiT, and then, through the KRRiT, over the TVP (Wąsicka-Sroczyńska, 2019). After referring to these events and comparing them to the developments of 2015 and 2016, one can form clear conclusions. The amendments adopted at the end of 2015 and in mid-2016 brought about a radical change in the functioning of the KRRiT and public broadcasters. Formally, the KRRiT still existed because it was grounded in the Constitution, additionally, PiS did not have enough seats to be able to remove the relevant provision from the Constitution. However, it became largely marginalized after being deprived of any decision-making power regarding the public radio and television, which in turn became completely subordinated (in terms of personnel and program) to the ruling party.

\section{POLITICIZATION IN JOURNALISTS' EXPERIENCE AT THE TVP}

The media law directly influences journalism practices at the TVP. Today's media, by transmitting various ideas and viewpoints, ought to inspire democratic processes and influence the building of a mature, citizen-governed society. It is the public media's task to encourage citizens to take part in public life. However, as various media make known the mechanics by which politics operate, public trust falls, not only in politicians and public officials, but also in journalists. The authors raise the hypothesis that TVP has been subject to political processes (RQ2). Whether their work has been affected by direct or indirect actions on the members of the political class seems an essential question when assessing journalists.

Research into TVP journalists - those who prepare network programs and take responsibility for their content by influencing what is covered - may provide an idea of how TVP functions and reveal the factors that influence the program's content through their news creation, news selection, and news agenda. Is the political pressure important for the choice of topics in journalists' practice at TVP? Is the political pressure the crucial factor behind news creation? Is the political pressure an important factor behind news selection?

A group of $20(\mathrm{~N}=20)$ TVP journalists were selected according to the following criteria: they had to have worked at the TVP S.A. for at least two years, and remain employed at the time of interview. However, only one participant 
of the study was employed in TVP after 2015. It was also essential that they came from different areas in Poland. It is worth noting here, however, that some of them worked both in Warsaw (the central station) and at the regional stations far from the capital. Interviews were conducted with journalists from the regional offices in Wrocław, Poznań, Kraków, Gdańsk, Białystok, Szczecin, Bydgoszcz, Kielce, Opole, and Łódź, as well as from the central office in Warsaw. The aim was the proportional participation of journalists from different parts of Poland, of different generations, women and men. The researchers sent 200 e-mails asking for an interview and only 10 of them both received positive response and met the assumed criteria. More interlocutors were found thanks to personal contacts. The selected group was sufficient to obtain valuable and extensive empirical material. It was important to include various age groups and journalists specializing in a variety of areas, such as culture, sport, agriculture, information, or social issues, as well as documentary filmmakers with experience in news journalism. However, news journalists predominated (14) in this group. They were more willing to participate in the study. All interviews were recorded on a portable digital device and were transcribed. Each of the interview subjects were coded and anonymized. All interviews were conducted in Autumn 2019 (August-September) by one researcher. Each respondent was given an initial, and their gender was indicated. Their age in years was given. Further variables were " $\mathrm{R}$ " for an employee of a regional station, "C" for one working for the central network, and seniority within TVP.

In the course of analysis, four thematic categories were distinguished:

1. the visible change of TVP after 2015,

2. the political pressure on journalists from management (editors, directors, chairman),

3. censorship and self-censorship,

4. interference in the shape of news for political reasons.

The subjects had also witnessed personnel changes and even purges of those who had run the network following the elections in 2015. The majority (16) of the subjects spoke either directly or between the lines about the threatening atmosphere that prevailed after those changes. During the research, some interesting phenomena were identified. We can indicate the effects of the politicization of TVP that are directly related to news shaping by dismissing disobedient journalists from work (excluding politically disobedient journalists from interesting and beneficial tasks), and by self-censorship (avoiding the politically suspicious subjects by journalists and editors according to experts' selections). 
The very effective instrument of shaping news, which is positive for the government, was achieved by releasing disobedient journalists. This could be done in two ways - by terminating the contract, or by forcing a journalist to leave work by themselves. The following quotations from the interviews illustrates the described problem:"In Warsaw (central newsroom) none of my colleagues left, so they got rid of experienced journalists. They either released them, or they (editors) passed over them in the schedule tasks" (P/female/news journalist/C/42/21). There was always a change of staff when the new director came. But there have been no such dismissals like recently" (T/male/news journalist/C/R/38/11).

The strategy of replacing experienced journalists with new workers has continued. Further, new staff were recruited from commercial right-oriented media like Republika Television (affiliated to PiS), Trwam Television (Catholic media), or right-oriented Internet influencers. This recruitment process was launched by Jacek Kurski and his new directors in regional offices, who had come after 2015. An effect of the exchange was a lowered level of journalist research, objectivity, impartiality, and cooperation with the rest of the newsroom team, which can be seen in the following excerpts from the interviews: "People from Trwam Television came. They cannot do anything, they do not trust anyone, but they prepare materials that favor the government (PiS). They cannot edit, make news, and they do not ask anyone" (N/male/news journalist/C/R/30/5).

One of the journalists recruited after 2015 described his work at the TVP: "I'm very satisfied with this job. I don't feel any political pressure" (B/male/news journalist/C/28/3).

It is worth adding that this young journalist had been recruited by the new management. During the interview he declared and confirmed his strong loyalty to PiS.

The atmosphere in the newsroom was not conducive for collaboration and exchanges of experience in opinion of the majority of participants (14). Moreover, journalists were afraid of their future dismissals. As such, they avoided any subject that could have been interpreted as being against the ruling party. The effect was essentially self-censorship. The interview subjects also indicated cases of removing the controversial content from political stakes. The following shows an example of self-censorship:

I know that if I present an issue that in some way is positively connected to the opposition, they won't allow it, so I try to avoid such material. (G/female/news journalist/C/41/15) 
I had prepared some material in which some local officials, connected to the opposition, appeared. They cut this fragment and told me I wasn't allowed to show it. It was a neutral news report about Easter breakfast tables. (D/male/news journalist/R/49/30)

One of the interviewed journalists from the regional office gave an example of a tracking of their private Facebook account by the TVP's authorities from the central office in Warsaw. Regional stations have to be subordinated to the central authorities. The financial, HR and the other strategic matters are decided at the central level (Węglińska, 2018). The journalist received a direct order from the regional director to get rid of any posts casting the opposition in a positive light or critical of the ruling party on Facebook. The regional director explained to the journalist that the order came from the central office. This type of intimidation also led to self-censorship. As a result, the journalist was very cautious in their news creation and selection. The governmental-political orientation in news creation prevails in the following example:

We are being closely monitored on social media by the TVP's authorities. I had such a case. I removed all content on my private Facebook account, as it was politically unacceptable for the TVP authorities. It was nothing controversial; some discussion with friends, jokes. The report about me came from Warsaw (central network). I am also very careful about my topic selection. I look for those that show the ruling party positively. (K/female/news journalist/R/C/43/18)

Further, three interview subjects mentioned a "blacklist” of experts, journalists, and artists at TVP:

There is a blacklist of experts. We cannot invite them. (N/male/news journalist/ $\mathrm{C} / \mathrm{R} / 30 / 6)$

Kayah (pop-singer) and Młynarski (dead poet/songwriter) are blacklisted. Kayah demonstrated against PiS. (M/female/news and entertainment journalist/C/45/20)

Even journalists at TVP who work in the entertainment formats revealed the same information about blacklisted people. There was also a blacklist for artists that were somehow associated with the opposition who could not be broadcast at TVP. The problem is that none of the interviewed journalists saw that list. One of them said that Samuel Pereira, the editor-in-chief of TVP Info (24/7 news 
channel) had black lists from Jacek Kurski. The majority of participants (18) confirmed the deep change in TVP taking place for political reasons.

These results show that the political pressures were a very important factor in the selection of information and news construction at TVP. Further, the atmosphere among journalists in the newsroom was getting worse since the recent appointment of the Chairman of TVP Jacek Kurski. The problems within the teams were related to distrust and suspicion, both vertically and horizontally. The problem of censorship and self-censorship was noticeable at TVP. All mentioned factors are significant in news construction, as news broadcasts at TVP were not objective, comprehensive, and impartial. There were political restrictions about experts, guests, and artists invited or broadcast. The one-sided, political perspective of the PiS government has dominated TVP since 2016.

\section{POLITICIZATION OF PUBLIC MEDIA: CASE STUDY OF THE MAIN NEWS PROGRAM ON POLISH TELEVISION}

The analysis of the process of politicization of the media requires reference to source materials. Therefore, this case study covers TVP1's Newsnight program during the period of February 4-10, 2019 (seven editions). The material for the analysis was selected randomly from among 21 week-long (seven editions) sets. There were no game-changing political events during the time.

The single news was selected as a basic research unit and defined as the smallest, constitutive element of a television news program (Seklecka, 2017) or "a distinct part within a news program structure, consisting of the content starting from a presenter's introduction up to the next news" (Mrozowski \& Popadiak-Kuligowska, 2016, p. 5).

Seventy-one single items of news were determined in the analyzed period. The analysis of the sample material was based on a key code including fundamental categories important for the topic of politicization. The following basic data were gathered: date of emission, order of news, the presenter, tenor of the relevant news type, news ticker narration, main and secondary topics of a news, figures presented in material (a journalist, an expert, a commentator, an official), graphic materials supporting narration (infographics, diagrams, tables), language, and application of alternative propaganda techniques. The coding of the material did not require interpretation, except in one of the categories, and was handled by one researcher. 
Except for a journalist responsible for the material, 301 figures in total were presented in the analyzed news, consisting of: politicians (111 times), officials (47 times), experts (34 times), journalists (as external commentators; 31 times), and other people (78 times). The last group included people that participated in street surveys, as an example of the so-called vox populi. It is worth noting that the opinions of the "ordinary people" coincided with the narration of the news in almost all cases. On the other hand, the domination of politicians who appeared to be more important than the experts and commentators in the news programs can be considered as an indication of the politicization of the media, especially for the media in the CEE countries.

Another important observation is the flagrant disproportion between the airtime given to the representatives of the governing camp (prime minister, members of the government, parliamentary majority) and that for the opposition. This is an issue of great importance because the public broadcaster in Poland is legally obliged to realize the remit of the public media, as is the case in other CEE countries.

Detailed analysis reveals that the representatives of the governing party were presented 59 times in total in the analyzed period, as follows: prime minister (7), ministers (25), Marshal of the Sejm (1), members of PiS (24), and members of the coalition party Solidarna Polska (2). Representatives of the opposition were presented seven times, and in the other materials, foreign politicians (it was the time of the presidential crisis in Venezuela), former politicians (14), and former oppositionists (7).

Another feature revealing the politicization of the media refers to the journalists in the roles of experts and commentators on TVP1's Newsnight program. Just like in the case of the politicians, a significant disproportion between the journalists who supported the narrative of the news and those presenting a critical attitude was found. Media representatives were presented 31 times in the analyzed period. From as many as 21 times, these were journalists supporting and positively evaluating activities of the governing camp and criticizing the opposition at the same time, as follows: W Sieci (6), Do Rzeczy (3), Gość Niedzielny (1), and Gazeta Polska (4) for the weeklies; (6) times from the TVP journalists; and (1) time from representatives of the Press Agency. In the other 10 news types, there were representatives of specialist media with neutral and expert comments. Representatives of the media that were critical to the government were not cited even once. It can be said that the public media journalists and editors broke article 21 of the Broadcasting Act by obligating public media to pluralism and impartiality. 
A tenor of the news types was also analyzed. They were clearly positive and supported the government in 34 types of news, and clearly negative in 29 types of news. The latter concerned either the activity of the opposition or of the global news (e.g., the leadership conflict in Venezuela). A neutral tenor was noted for six materials, and was undefinable for two.

Politicization was also proved by a selection of the texts on news tickers. A few were proposals and insinuations, for example, kto chce popsuć marke polskiej żywności? [who wants to spoil the Polish food brand?], and komu przeszkadza silna telewizja publiczna? [whom does a strong public television bother?]. The others underlined support for the authorities, for example, Polacy stawiaja na PiS [the Poles bet on PiS], or on critical attitude toward politicians perceived as the critics of the ruling camp, for example, Donald Tusk $w$ ogniu $k r y t y k i$ [Donald Tusk under attack]. A critical attitude toward some EU states was also emphasized, such as on the ticker featured as a comment to the German chancellor Angela Merkel's visit to Japan, Regermanizacja i nowy marsz na wschód [re-Germanization and the new march to the East].

Classic propaganda techniques were also applied to the analyzed materials. The technique of repetition was one of the most often used, aiming at the enhancement of the news tenor. The same historical materials concerning journalists' criticism of the governing camp were used three times in seven analyzed programs (by Tomasz Lis, Editor-in-Chief of Newsweek weekly, and Bogusław Chrabota, Editor-in-Chief of Rzeczpospolita weekly), and in documentary film clips used for attacking opposition politicians which were supported by a comment from a journalist presenting the news.

Public media in Poland were criticized before 2015 for (among other reasons) the unequal treatment of political parties and candidates in parliamentary and presidential elections. However, the analyzed editions of TVP1's Newsnight, just as the interviews mentioned above, do reveal significant increase in the politicization and partiality of this media. The results of this study are in line with the conclusions of the previous research (Dopierała \& Ossowski, 2018). They confirm the increasing, negative changes of this program, and prove both its politicization and instrumental usage of the news program by politicians fighting against each other. It was also confirmed in the preliminary Statement of the Organization for Security and Co-operation in Europe (OSCE) representatives concerning the observation of the results of parliamentary elections in Poland (ODIHR/OSCE, 2019, pp. 12-14). This is a classic example of the politicization of the media. 


\section{CONCLUSION}

In the three empirical parts of the presented analysis, there was a significant increase in the level of politicization at TVP since 2015. If Oniszczuk's (2011) three politician-media relationship types (the participation of authorities, instrumentalization, and autonomy versus symbiosis) are taken into consideration, it becomes clear that the public media in Poland is treated instrumentally (as a political booty) by politicians. The authors can also indicate that the level of political parallelism at TVP is very high (Hallin \& Mancini, 2004).

Regarding the politicization, we conclude that in the opinion of the interviewed journalists, it is the political class that is responsible for the present situation in public television. The journalists are disappointed with political decision makers, yet they were conscious of their dependence on them (RQ1). The interview subjects had also witnessed personnel changes and even purges to those who had run the network following the elections in 2015. In the majority of the interviews conducted, the journalists spoke between the lines of the threatening atmosphere that prevailed after those changes. The atmosphere and internal activities of the TVP's authorities, who are related to the ruling party, influenced news creation and selection (RQ2). The public intentions such as objectivity and impartiality were neglected in news shaping and selection for political reasons (RQ2). The direct effects of these processes were censorship, self-censorship, and guests and expert selection that was directly related to news creation and selection (RQ2, RQ4).

The analysis allowed the authors to view a specific pattern of conduct reproduced, to a greater or lesser extent, by the political groups representing different sides of the political scene. It has been observed that political parties very eagerly put forward further projects aimed at amending the current media law. They treated the option of legislation as a mechanism to achieve their particular interests, rather than as a tool to ensure the independence of public broadcasters (RQ3). Through changes in legal regulations, they changed personnel in the National Broadcasting Council and in the authorities of public broadcasters. In this way, they aimed to carry out visual, that is, personal and program changes using the antennas of public broadcasters. The natural consequence of this type of change was the modification of the current way of creating information. The information had to be adapted to the changing political situation, and had to be approved by the new ruling party, through which it tried to increase the number of its supporters. 
According to the last research question (RQ4), it should be emphasized that the politicization process has left its mark on many areas of preparation of the Newsnight service. Significant discrepancies in airtime devoted to the policies of the ruling party and the opposition were noted. The selection of experts and commentators was also partisan, and those who favored the ruling party dominated. Finally, the language, including that which appeared on information tickers, was persuasive.

\section{REFERENCES:}

Act of June 29, 1995. Ustawa $z$ dnia 29 czerwca 1995 r. o zmianie ustawy o radiofonii i telewizji oraz o zmianie niektórych innych ustaw [Act of 29 June 1995 Amending the Broadcasting Act and Some Other Acts]. Journal of Laws 1995 No. 142, item 701. Act of April 2, 2004. Ustawa $z$ dnia 2 kwietnia 2004 r. o zmianie ustawy o radiofonii $i$ telewizji [Act of 2 April 2004 Amending the Broadcasting Act]. Journal of Laws 2004 No. 91, item 874.

Act of April 21,2005. Ustawa $z$ dnia 21 kwietnia 2005 r. o oplatach abonamentowych [Act of 21 April 2005 on License Fees]. Journal of Laws 2005 No. 85, item 728.

Act of December 29, 2005. Ustawa $z$ dnia 29 grudnia 2005 r. o przeksztatceniach i zmianach $w$ podziale zadań $i$ kompetencji organów państwowych właściwych $w$ sprawach łaczności, radiofonii i telewizji [Act of 29 December 2005 on Transformations of and Modifications to the Division of Tasks and Powers of State Bodies Competent for Communications and Broadcasting]. Journal of Laws 2005 No. 267, item 2258.

Act of April 25, 2006. Ustawa $z$ dnia 25 kwietnia 2006 r. o zmianie ustawy o radiofonii $i$ telewizji [Act of 25 April 2006 Amending the Broadcasting Act]. Journal of Laws 2006 No. 83, item 574.

Act of August 6, 2010. Ustawa $z$ dnia 6 sierpnia 2010 r. o zmianie ustawy o radiofonii $i$ telewizji oraz o optatach abonamentowych [Act of 6 August 2010 Amending the Broadcasting Act and Concerning License Fees]. Journal of Laws 2010 No. 152, item 1023.

Act of December 30, 2015. Ustawa $z$ dnia 30 grudnia 2015 roku o zmianie ustawy o radiofonii i telewizji [Act of 30 December 2015 Amending the Broadcasting Act]. Journal of Laws 2015, item 25.

Act of June 29, 2016. Ustawa $z$ dnia 29 czerwca 2016 r. o Radzie Mediów Narodowych [Act of 29 June 2016 on the National Media Council]. Journal of Laws 2016, item 929.

Adamowski, J. (2007). Media masowe w kampaniach politycznych [Mass Media in Political Campaigns]. In: D. Waniek, \& J.W. Adamowski (Eds.). Media masowe w praktyce społecznej [Mass Media in Social Practice] (pp. 63-79). Warszawa: Aspra.

Brüggemann, M., Engesser, S., Büchel, F., Humprecht, E., \& Castro, L. (2014). Hallin and Mancini Revisited: Four Empirical Types of Western Media Systems. Journal of Communication, 64(6), 1037-1065. DOI: 10.1111/jcom.12127. 
Brüggemann, M., Büchel, F., Humprecht, E., Castro Herrero, L., \& Engesser, S. (2016). Building Empirical Typologies with QCA: Toward a Classification of Media Systems. The International Journal of Press/Politics, 21(2), 209-232. DOI: $10.1177 / 1940161215626567$.

Brüggemann, M., Engesser, S., Büchel, F., Humprecht, E., Castro Herrero, L. (2017). Rethinking Hallin and Mancini Beyond the West: An Analysis of Media Systems in Central and Eastern Europe. International Journal of Communication, 11(27), 4797-4823.

Bulletin (2015, December 30). Biuletyn z posiedzenia Komisji do Spraw Energii i Skarbu Państwa (nr 7) i Komisji Kultury i Środków Przekazu (nr 7) [Bulletin Concerning a Meeting of the Energy and State Treasury Committee (No. 7) and the Culture and Media Committee (No. 7)].

Chadwick, P. (2013). Prologue. In: G. Ferrell Love, \& F. Martin (Eds.). The Value of Public Service Media (pp. 11-18). Göteborg: Nordicom.

Chruściak, R. (2007). Krajowa Rada Radiofonii i Telewizji w systemie politycznym $i$ konstytucyjnym [National Broadcasting Council in Political and Constitutional System]. Warszawa: Elipsa.

Creswell, J.W. (2013). Qualitative Inquiry and Research Design: Choosing among Five Approaches ( $3^{\text {rd }}$ Ed.). Washington, D.C.: SAGE.

Dobek-Ostrowska, B. (2011). Italianization (or Mediterraneanization) of the Polish Media System. In: D.C. Hallin, \& P. Mancini (Eds.). Comparing Media Systems beyond the Western World (pp. 26-50). Cambridge: Cambridge University Press. DOI: 10.1017/CBO9781139005098.004.

Dobek-Ostrowska, B. (2015). 25 Years after Communism: Four Models of Media and Politics in Central and Eastern Europe. In: B. Dobek-Ostrowska, \& M. Głowacki (Eds.). Democracy and Media in Central and Eastern Europe 25 Years On (pp. 11-44). Frankfurt am Main, Germany: Peter Lang.

Dobek-Ostrowska, B. (2018). Mediatyzacja polityki w tygodnikach opinii w Polsce między polityzacją a komercjalizacją [Mediatization of Politics in Opinion Weekly Magazines: Between Politicization and Commercialization]. Zeszyty Prasoznawcze [Media Research Issues], 61(2), 224-246. DOI: 10.4467/22996362PZ.18.016.9111.

Dobek-Ostrowska, B. (2019). Polish Media System in a Comparative Perspective: Media in Politics, Politics in Media. Frankfurt: Peter Lang.

Dopierała, W., \& Ossowski, S. (2018). Polityzacja audycji informacyjnych w Polsce na przykładzie „Wiadomości” TVP i „Faktów” TVN [The Politicization of the News Programs in Poland: The Case of "Newsnight" on TVP and "Facts" on TVN]. Com. press, 2(1), 4-25.

Grochowski, R. (2015). Krajowa Rada Radiofonii i Telewizji jako konstytucyjny organ kontroli i ochrony prawa [National Broadcasting Council as a Constitutional Regulator]. In: M. Barańska, A. Balczyńska-Kosman, M. Balcerek-Kosiarz, \& K. Duda (Eds.). Polityka medialna $w$ Polsce. Bilans dwudziestolecia obowiązywania Ustawy o Radiofonii i Telewizji (pp. 101-114). Poznań: Wydawnictwo UAM. 
Haggard, S., \& You, J.S. (2015). Freedom of Expression in South Korea. Journal of Contemporary Asia, 45(1), 167-179. DOI: 10.1080/00472336.2014.947310.

Hallin, D.C., \& Mancini, P. (2004). Comparing Media Systems: Three Models of Media and Politics. Cambridge: Cambridge University Press.

Hallin, D.C., \& Mancini, P. (2012). Comparing Media Systems: Between Eastern and Western Europe. In: P. Gross, \& K. Jakubowicz (Eds.). Media Transformation in the Post-Communist World: Eastern Europe Tortured Path to Change (pp. 15-32). Plymouth, UK: Lexington Book.

Hess, A. (2010). Relacje mediów masowych i partii politycznych jako przedmiot badań studiów nad komunikacją polityczną: wprowadzenie [Mass Media and Political Party Relations as a Subject of Research in Political Communication Studies: An Introduction]. In: K. Sobolewska-Myślik, A. Hess, \& K. Kowalczyk (Eds.). Polska scena polityczna. Środowiska - komunikacja polityczna - strategie [The Political Scene of Poland: Social Environment - Political Communication - Strategies] (pp. 131-140). Kraków: Wydawnictwo UJ.

IAR (2015, December 30). List Fransa Timmermansa, wiceszefa KE, do Waszczykowskiego $i$ Ziobry. Chodzi o ustawe medialna [Letter from Frans Timmermans, Vice-President of the European Commission, to W. Waszczykowski and Z. Ziobro, Concerning the Media Law]. Retrieved June 24, 2020 from: https://wiadomosci.dziennik.pl/media/ artykuly/509402,list-wiceszefa-ke-franzsa-timmermansa-do-polskich-wladz-wsustawy-medialnej.html.

IAR (2016a, January 3). Komisarz UE ostrzega w związku $z$ ustawa medialna. Rzecznik prezydenta odpowiada [European Commissioner Issues a Warning in Connection with the Media Law. The President's Spokesperson Responds]. Retrieved June 24, 2020 from: https://wiadomosci.dziennik.pl/media/artykuly/509576,faz-komisarzue-gunther-oettinger-ostrzega-polske-w-zwiazku-z-ustawa-medialna.html.

IAR (2016b, January 6). Szef Europejskiej Unii Nadawców: Z takq ustawa medialnq Polska do Wspólnoty by nie weszła [President of the EBU: Poland Wouldn't Have Joined the Community with This Media Law]. Retrieved June 24, 2020 from: https:// wiadomosci.dziennik.pl/swiat/artykuly/509697,szef-ebu-o-ustawie-medialnej-ztakim-prawem-polska-do-unii-europejskiej-by-nie-weszl.html.

Jakubowicz, K. (2007). Media publiczne. Poczatek końca czy nowy poczatek [Public Media: The Beginning of the End or a New Beginning]. Warszawa: Wydawnictwa Akademickie i Profesjonalne.

Konstytucja RP z dnia 2 kwietnia 1997 r. [The Constitution of the Republic of Poland of 2 April 1997]. Journal of Laws 1997 No. 78, item 438.

Morgan, D.L. (2013). Integrating Qualitative and Quantitative Methods: A Pragmatic Approach. Thousand Oaks, CA: Sage.

Mrozowski, M., \& Popadiak-Kuligowska, T. (2016, March). Ekspertyza programów informacyjnych głównych wydań TVP1 Wiadomości, TVN Fakty, Polsat Wydarzenia na zlecenie KRRiT z okresu 4.02.2016 r. do 11.02.2016 r. Raport końcowy [Expertise of the News Programs of the Main Editions of TVP1 Wiadomości, TVN Fakty, Polsat. Events from February 4, 2016 to February 11, 2016. Final Report]. 
Retrieved from: http://www.krrit.gov.pl/Data/Files/_public/Portals/0/komunikaty/12.04.2016/krrit_eksperyza.pdf.

ODIHR/OSCE (2019). Limited Election Observation Mission. Republic of Poland, Parliamentary Elections, 13 October 2019. Statement of Preliminary Findings and Conclusions. Retrieved from: https://www.osce.org/odihr/elections/ poland/435932?download=true.

Oniszczuk, Z. (2011). Mediatyzacja polityki i polityzacja mediów. Dwa wymiary wzajemnych relacji [Mediatization of Politics and Politicization of the Media: Two Dimensions of the Relationship]. Studia Medioznawcze [Media Issues], 4, 12-22.

Paper No. 158 (2015). Sejm RP VIII kadencji, Druk nr 158 z dnia 28 grudnia 2015 r. Projekt ustawy o zmianie ustawy o radiofonii i telewizji [The Sejm of the Republic of Poland, $8^{\text {th }}$ Term, Paper No. 158 of 28 December 2015 - A Draft Law Amending the Broadcasting Act].

Paper No. 444 (2016). Sejm RP VIII kadencji, Druk nr 444 z dnia 20 kwietnia 2016 r. - Przepisy wprowadzające ustawę o mediach narodowych i ustawę o składce audiowizualnej [The Sejm of the Republic of Poland, $8^{\text {th }}$ Term, Paper No. 444 of 20 April 2016 - Provisions Introducing the National Media Act and the Audiovisual Fee Act].

Paper No. 592 (2016). Sejm RP VIII kadencji, Druk nr 592 z dnia 7 czerwca 2016 r. - Projekt ustawy o Radzie Mediów Narodowych oraz o zmianie niektórych ustaw [The Sejm of the Republic of Poland, $8^{\text {th }}$ Term, Paper No. 592 of 7 June 2016 A Draft Law on the National Media Council and Amending Some Other Acts].

Piontek, D. (2011). The Tabloidization of Political Discourse: The Polish Case. Central European Journal of Communication, 4(2), 275-292.

Przewodniczący KRRiT, Do druku nr 592 z 14 czerwca 2016 r. - Opinia KRRiT w stosunku do poselskiego projektu o Radzie Mediów Narodowych oraz o zmianie niektórych ustaw [Chairman of the National Broadcasting Council, with Regard to Paper No. 592 of 14 June 2016 - the National Broadcasting Council's Opinion about Sejm Deputies' Draft Law on the National Media Council and Amending Some Other Acts].

Record of a Joint Meeting... (2015, December 31). Zapis z posiedzenia Komisji Gospodarki Narodowej i Innowacyjności (9.) i Komisji Kultury i Środków Przekazu (5.) [Record of a Joint Meeting of the National Economy and Innovativeness Committee (9.) and the Culture and Media Committee (5.)] z 31 grudnia 2015.

Report of the Sejm's $7^{\text {th }}$ Session (2015, December 29). Sprawozdanie z 7. posiedzenia Sejmu Rzeczypospolitej Polskiej, 29 grudnia 2015.

Report of the Sejm's $7^{\text {th }}$ Session (2015, December 30). Sprawozdanie z 7. posiedzenia Sejmu Rzeczypospolitej Polskiej, 30 grudnia 2015.

Report of the Sejm's $20^{\text {th }}$ Session (2016, June 9). Sprawozdanie z 20. posiedzenia Sejmu Rzeczypospolitej Polskiej, 9 czerwca 2016.

Report of the Sejm's $21^{\text {st }}$ Session (2016, June 21). Sprawozdanie z 21. posiedzenia Sejmu Rzeczypospolitej Polskiej, 21 czerwca 2016.

Reporters Without Borders (2019). Poland. Retrieved from: https://rsf.org/en/poland. 
Repucci, S. (2019). Media Freedom: A Downward Spiral. Retrieved from: https:// freedomhouse.org/report/freedom-media/freedom-media-2019.

Schroeter, M. (2018). "All This Is a Boon to Britain's Crumbling Democracy": MetaReporting about the TV-Debates in the British General Election 2015. In: M. Kranert, \& G. Horan (Eds.). 'Doing Politics': Discursivity, Performativity and Mediation in Political Discourse. Discourse Approaches to Politics, Society and Culture (pp. 361-382). Amsterdam: John Benjamins. Retrieved from: http://centaur.reading. ac.uk/73398/.

Seklecka, A. (2017). Rytuały medialne w komunikowaniu masowym. Przypadek polskich telewizyjnych serwisów informacyjnych „Fakty” TVN i „Wiadomości” TVP [The media rituals in mass communication: The Case of Facts on TVN and Newsnight on TVP]. Torun: Wydawnictwo UMK.

Smyth, R., \& Oates, S. (2015). Mind the Gaps: Media Use and Mass Action in Russia. Europe-Asia Studies, 67(2), 285-305, DOI: 10.1080/09668136.2014.1002682.

Splendore, S., \& Domaneschi, L. (2017). Entertainment Is Serious Stuff: The Politicisation of Everyday Laughs. Contemporary Italian Politics, 9(3), 302-317. DOI: 10.1080/23248823.2017.1391508.

Strömbäck, J. (2008). Four Phases of Mediatization: An Analysis of the Mediatization of Politics. The International Journal of Press/Politics, 13(3), 228-246. DOI: $10.1177 / 1940161208319097$.

Surowiec, P., Kania-Lundholm, M., \& Winiarska-Brodowska, M. (2020). Towards Illiberal Conditioning? New Politics of Media Regulations in Poland (2015-2018). East European Politics, 36(1), 27-43. DOI: 10.1080/21599165.2019.1608826.

Tocia, M. (2018). Freedom of Speech in Media Communication: The Censorship and Politicisation of Media Institutions. Diversité et Identité Culturelle en Europe (DICE Review), 15(2), 205-216.

Valcke, P., Picard, R., Sükösd, M., Klimkiewicz, B., Petkovic, B., dal Zotto, C., \& Kerremans, R. (2010). The European Media Pluralism Monitor: Bridging Law, Economics and Media Studies as a First Step towards Risk-Based Regulation in Media Markets. Journal of Media Law, 2(1), 85-113. DOI: 10.1080/17577632.2010.11427355.

Wąsicka, M. (2014). Politicisation of the Polish Media or Mediatisation of Polish Politics? Where the Worlds of the Media and Politics Permeate. Srodkowoeuropejskie Studia Polityczne [Central European Political Studies], 1, 141-155. DOI: 10.14746/ ssp.2014.1.10.

Wąsicka-Sroczyńska, M. (2019). Polskie parlamentarne partie polityczne wobec Krajowej Rady Radiofonii i Telewizji i nadawców publicznych [Polish Parliamentary Parties Attitudes towards the National Broadcasting Council and Public Broadcasters]. Poznań: Wydawnictwo UAM.

Węglińska, A. (2018). Dziennikarze Telewizji Publicznej w Polsce. Między polityką, misją a rynkiem [The Journalists of Public Television in Poland: Between Political Pressures, Mission, and the Market]. Wrocław: Wydawnictwo Naukowe Dolnośląskiej Szkoły Wyższej. 